\title{
PENYEBAB PERCERAIAN DALAM KELUARGA DI KOTA PALU
}

\author{
Fatmawati, Kasmiati
}

\begin{abstract}
Divorce is a result of the inability of husband and wife to overcome problems in the household. Based on data from the Palu City Ahama Court, husband and wife's opinion occurred a lot in palu city. For this reason, this study aims to explain the causes of husband and wife divorce in Palu City. Through field research by reviewing and analyzing data from interviews, observations, and dolumentation, qualitative analysis can be done. From the results of the analysis, it was found that the phenomenon of the cause of divorce in Palu City in terms of internal in the household environment occurred because one party left the obligation to make a living for the survival of the family with a percentage of $45.38 \%$, the occurrence of moral crises such as gambling, drunkenness with a percentage of $6.62 \%$, excessive jealousy that caused heartache with a percentage of $3.01 \%$, Disputes that occur continuously with a percentage of $29.51 \%$, unhealthy polygamy $1.80 \%$. Furthermore, another cause of divorce in Palu City is in terms of external factors, is because parents who interfere too much in household affairs with a percentage of $8.20 \%$, other parties as third parties by spreading slander whose percentage reaches $2.40 \%$.
\end{abstract}

Keywords: Divorce, Family, Husband, Wife, and Religion.

\section{PENDAHULUAN}

Pernikahan merupakan suatu wadah yang dapat mempersatukan dua insan yang berlainan jenis kelamin dengan sah. Melalui pernikahan maka akan terbentuk keluarga baru. Pernikahan bukan saja sebagai wadah hubungan antara suami dan istri atau anak-anak dan orang tua, tetapi juga sebagai suatu rangkaian tali hubungan antara jaringan sosial dan anggota keluarga, dan juga jaringan yang lebih besar, yaitu masyarakat. Jaringan keluarga yang akan menikah selalu dihubungkan oleh beberapa jaringan-jaringan keluarga lainnya atau keluarga yang lebih jauh. Dari sini, kedua keluarga itu mempunyai kedudukan dalam sistem lapisan sosial. ${ }^{1}$

\footnotetext{
${ }^{1}$ Adrianto, Psikolog Sosial (Jakarta: Erlangga, 2002), 8.
} 
Dalam teori pertukaran menegaskan bahwa pernikahan merupakan suatu proses pertukaran antara hak dan kewajiban serta penghargaan dan kehilangan yang terjadi di antara suami dan istri. Pernikahan merupakan proses dua individu yang hidup dan tinggal bersama. Pernikahan menyatukan latar belakang budaya, keinginan serta kebutuhan mereka berbeda. Hal ini membuat proses pertukaran dalam pernikahan harus senantiasa dirundingkan serta disepakati bersama. Artinya, jika istri pindah ke tempat keluarga suami, yang di Kota Palu disebut dengan patrilokal, atau laki-laki masuk dalam keluarga istri sistemnya disebut matrilokal, dan jika mereka pindah di tempat sendiri disebut neolocality, maka hal ini harus diputuskan atas dasar kesepakatan bersama-sama. ${ }^{2}$ Kesepakatan ini berdasarkan hasil observasi, senantiasa dijunjung tinggi oleh karena tidak jarang keluarga melakukan perceraian atau konflik dalam rumah tangga. Konflik ini sering terjadi akibat perbedaan keinginan, dan tidak jarang pula, terjadi karena keluarga dalam rumah tangga bercerai karena pihak keluarga lain yang terlalu banyak ikut campur urusan rumah tangga misalnya, ibu, saudara-saudara maupun keluarga lainnya.

Pernikahan bagi masyarakat di Kota Palu merupakan ritual yang sering diwarnai dengan rasa kebersamaan atau saling membantu satu sama lain sehingga apapun pekerjaan berkaitan dengan produktivitas akan ditinggalkan demi untuk meramainkan acara pesta pernikahan. Hal in terjadi pula ketika anggota keluarga atau tetangga dalam keadaan berduka. Budaya berjalan secara turun temurun, bahkan terkadang meninggalkan pekerjaan sampai seminggu hanya untuk merayakan pesta tersebut. Pernikahan yang sesungguhnya bertujuan untuk membentuk suatu keluarga yang bahagia, tentunya berhubungan dengan masalah keturunan di mana saja merupakan tujuan pernikahan di samping pemeliharaan dan pendidikan yang menjadi hak dan kewajiban orang tua. Pernikahan mempunyai arti penting bagi keluarga, maka pelaksanaannya senantiasa dimulai dan disertai dengan berbagai upacara lengkap dengan sesajen-sesajen. Kepercayaan ini sampai sekarang masih dipercaya sebagian masyarakat Kota Palu. ${ }^{3}$

${ }^{2}$ Soe'oed, Bunga Rampai Sosiologi Keluarga (Jakarta: Yayasan Obor Indonesia, 2009), 105.

${ }^{3}$ Mattulada, Sejarah Kebudayaan To Kaili Palu (Palu: Lembaga Penerbit Universitas Tadulako, 2010), 23. 
Budaya pernikahan di Kota Palu, sebagaimana dengan daerah lainnya, ditentukan oleh status sosial keluarga, misalnya pam Lemba itu akan berbeda prosesi pernikahannya dengan masyarakat biasa. Pada lingkungan Pam Lemba biasanya sang mempelai laki-laki menunggangi kuda yang telah disiapkan dan dihiasi sedemikian rupa sampai ke rumah mempelai perempuan. Begitu pula dengan hiasan rumah kedua mempelai diharuskan memasang walasuji untuk menghindari terjadinya "bala" (bencana). Saat hal ini terjadi, maka tujuan suatu pernikahan tidak akan tercapai dengan baik, dalam arti anak akan menjadi korban, baik korban perasaan atau kejiwaan, korban rasa kasih sayang maupun secara materi. ${ }^{9}$

Dalam perjalanan berkeluarga inilah, krisis keluarga sering terjadi. Krisis inilah yang menjadikan hubungan individu keluarga tidak lagi memiliki keuletan dan ketangguhan serta tidak lagi memiliki kemampuan fisik, materil, psikis, mental, dan spiritual guna hidup mandiri dan mengembangkan diri dan keluarganya untuk hidup harmonis dalam meningkatkan kesejahteraan lahir dan batin. Krisis keluarga yang ditimbulkan adalah pada hubungan sosial atau interaksi yang disharmoni, disebabkan oleh berbagai faktor dan hubungan sosial yang terjadi dalam keluarga yang semula hangat menjadi penuh kecurigaan pada gilirannya. Kondisi keluarga yang demikian itu akan menimbulkan perpecahan. ${ }^{4}$ Pernikahan yang awalnya dipandang sebagai dasar terbentuknya keluarga, atau sebagai basis dan sendi masyarakat maka pemilihan jodoh (calon suami atau istri) merupakan masalah dan hal yang sangat penting untuk diperhatikan dan ditempuh secara teliti dan cermat. Pemilihan jodoh yang tepat dapat menentukan tercapainya kehidupan yang harmonis dan sejahtera dalam suatu pernikahan mulai memudar. ${ }^{5}$

Idealnya, pernikahan yang disyariatkan Islam adalah pernikahan yang diliputi rasa kasih sayang dan saling cinta mencintai, yakni terbentuknya rumah tangga yang sejahtera, bahagia, dan kekal. ${ }^{6}$ Keluarga bahagia adalah keluarga yang memperhatikan adanya azas harmonis para individu dalam keluarga tersebut. Jika di

${ }^{4}$ P.R. Amato, Children's Adjustment to Divorce; Theories, Hypotheses and Empirical Soport (New Yor: Jurnal Mariage and Family, 1993), 56.

${ }^{5}$ Happy Marpaung, Masalah Perceraian; Alasan Dan Akibatnya (Bandung: Tons, 2003), 16.

${ }^{6}$ A. Mukti Ali, Beberapa Persoalan Agama Dewasa Ini (Jakarta: Rajawali Press, 2007), 34. 
antara suami istri timbul perbedaan yang akan membahayakan keutuhan keluarga mereka, maka hendaklah ditunjuk seorang penengah untuk mempertahankan keutuhan rumah tangganya sehingga tidak terjerumus kedalam perceraian. ${ }^{7}$ Perceraian yang disyariatkan Islam adalah upaya untuk menyelesaikan perselisihan yang tidak mungkin lagi didamaikan antara pihak yang berselisih, atau sebagai penenang bagi suami istri untuk melepaskan dirinya dari cengkeraman dan kesusahan dunia akibat salah paham dari salah satu pihak yang melalaikan kewajibannya yang merupakan tanggung jawab. ${ }^{8}$ Dengan mensyariatkan perceraian, Islam tetap memandang sebagai suatu yang musykil, yaitu yang tidak diinginkan karena bertentangan dengan azas-azas hukum Islam. ${ }^{9}$

Melalui perceraian inilah maka kesakralan dan makna perkawinan sudah tidak berarti. Pasangan yang akan bercerai sibuk mencari kebenaran akan keputusan mereka untuk berpisah. Mereka tidak lagi mempertimbangkan bahwa ada yang bakal sangat menderita dengan keputusan tersebut yaitu anak. Uniknya, fenomena perceraian ini marak terjadi bukan hanya di kalangan artis atau publik figur saja tapi juga di dalam keluarga sederhana, bahkan di dalam lingkungan pendidikan dan lingkungan yang tampak religius. Melihat fenomena semakin maraknya perceraian, maka tentu perlu diteliti penyebab perceraian terjadi. Apalagi saat ini angka perceraian di beberapa kota di Indonesia terus mengalami peningkatan, khususnya di Kota Palu yang memiliki jumlah penduduk 313.179 jiwa, menunjukkan data empiris 3 (tiga) tahun terakhir kasus cerai yang diproses di Pengadialn Agama Palu terus meningkat pada tahun 2018, 2019 dan 2020. Salah satu kota yang banyak terjadi kasus perceraiannnya adalah Kota Palu.

Berdasarkan data dari Kantor Pengadilan Agama Palu tersebut, menunjukkan bahwa tiga tahun terakhir ini, $80 \%$ kasus perceraian yang pengasuhan anak jatuh pada ibu. Dengan kondisi seperti ini maka Kota Palu menjadi menarik untuk dijadikan obyek penelitian tentang perceraian suami dan istri. Kota palu yang merupakan pusat pertemuan dari berbagai etnis, suku dan agama menyebabkan pula pernikahan antar suku yang tidak dapat dihindari, bahkan pernikahan antar agama dapat ditemukan di

${ }^{7}$ Said Thalib Al-Hamdani, Rishalatun Nikah (Jakarta: Pustaka Amani, 2000), 181.

${ }^{8}$ Marpaung, 123.

${ }^{9}$ M. Quraish Shihab, Tafsir Al-Misbah (Jakarta: Lentera Hati, 2006), 114. 
Fatmawati, Penyebab Perceraian ... | 154

Kota Palu, sehingga perbedaan persepsi dan keyakinan akan menjadikan rentan terjadi sebagai salah satu wujud penyebab perceraian. Dari sinilah, fokus penelitian adalah menjawab pertanyaan tentang penyebab perceraian di Kota Palu.

\section{METODE PENELITIAN}

Jenis penelitian ini field research, yakni penelitian lapangan yang menekankan pada konstruksi kualitatif dalam bentuk kegiatan observasi di lapangan. Observasi digunakan untuk menyelidiki hubungan atau menguji hipotesis. ${ }^{10}$ Penelitian observasi di sini dilakukan dengan berdasarkan kerangka kualitatif yang mengarah pada uraian deskriptif dan penjelasan (explanatory atau confirmatory), yaitu menjelaskan hubungan kausal dan pengujian hipotesis. Penelitian menyajikan temuan empiris berupa jawaban, ucapan, kata-kata dan tindakan atau perilaku subyek yang diamati dan dideskripsikan secara lebih rinci, jelas, dan akurat mengenai perceraian dalam keluarga di Kota Palu. Lokasi penelitian ini adalah Kota Palu. Penentuan lokasi ini secara umum didasari oleh karena Kota Palu merupakan pusat ibukota Provinsi Sulawesi Tengah yang merupakan kota utama pertemuan dari berbagai etnis, budaya, dan agama sehingga banyak ditemukan terjadi pernikahan campuran baik pernikahan antar agama, budaya maupun etnis. Kondisi inilah yang sering memancing terjadinya perceraian. Sumber data penelitian ini ada enam keluarga yang mengalami perceraian di Kota Palu. Penetapan ini dilakukan dengan terlebih dahulu melakukan pengamatan awal pada beberapa keluarga yang bercerai di Kota Palu. Proses penentuan sumber data dilakukan dengan cara snowball, artinya tergantung pada sejumlah informan yang telah diperoleh dapat memenuhi keperluan. ${ }^{11}$

Metode pengumpulan data dalam penelitian ini dilakukan dengan pengamatan (observation) yang dilakukan secara sistematis mengenai perceraian. ${ }^{12}$ Observasi yang dilakukan terhadap kondisi kehidupan keenam informan dan pengamatan terhadap dokumen-dokumen tertulis yang ada kaitannya dengan penelitian seperti informasi tentang potensi terjadinya perceraian di Kota Palu. Wawancara (interview)

\footnotetext{
${ }^{10}$ Sugiyono, Metode Penelitian (Yogyakarta: Rosdakarya, 2010), 8.

${ }^{11}$ Suharsimi Arikunto, Manajemen Penelitian (Jakarta: Rineka Cipta, 2013), 34.

${ }^{12}$ Sutrisno Hadi, Metode Research, 1st edn (Yogyakarta: Universitas Gajah Mada, 1986), 90.
} 
yang dilakukan untuk mendapatkan informasi secara langsung dengan mengungkapkan pertanyaan-pertanyaan pada informan. ${ }^{13}$ Dokumentasi yang dilakukan dengan mengumpulkan arsip dokumen yang relevan untuk digunakan sebagai bahan penyempurnaan penelitian. Data itu ada yang dicatat dan ada yang dicopy langsung, setelah itu penulis mengolahnya untuk dituangkan dalam laporan hasil penelitian ini, antara lain data perceraian yang diperoleh dari Kantor Pengadilan Agama Kota Palu Sulawesi Tengah.

Prosedur pengolahan data selama di lapangan dianalisis secara interaktif dan berlangsung secara terus menerus sampai tuntas, yang terdiri atas tiga aktivitas, yaitu data reduction, data display dan conclusion drawing/verification:: ${ }^{14}$ data reduction (reduksi data) yang dilakukan dengan merangkum, memilih hal-hal pokok, memfokuskan pada hal-hal penting, dicari tema dan polanya serta membuang yang tidak perlu. Dalam penelitian yang dilakukan data yang diperoleh dari lapangan jumlahnya cukup banyak, untuk itu perlu dicatat secara teliti dan rinci. Untuk itu perlu segera dilakukan analisis data melalui reduksi data. Dengan demikian data yang telah direduksi akan memberikan gambaran yang lebih jelas dan mempermudah penulis untuk melakukan pengumpulan data selanjutnya dan mencarinya bila diperlukan.

Karena metode yang digunakan dalam penelitian ini adalah deskriptif analitis maka dipslay data yang dilakukan lebih banyak dituangkan ke dalam uraian secara singkat. Ketiga, conclusion drawing / verification, yang dilakukan dengan menganalisis data kualitatif adalah penarikan kesimpulan dan verifikasi. ${ }^{15}$ Kesimpulan dalam penelitian kualitatif mungkin dapat menjawab rumusan masalah yang dirumuskan sejak awal, tetapi mungkin juga tidak, karena masalah dan rumusan masalah dalam penelitian kualitatif masih bersifat sementara dan akan berkembang setelah peneliti berada di lapangan. Setelah selesai di lapangan, simpulan-simpulan yang diperoleh dari tahap sebelumnya selanjutnya dianalisis dengan teknik deskriptif-

\footnotetext{
${ }^{13}$ Joko Subagio, Metode Penelitian Dalam Teori Dan Praktek (Jakarta: Rineka Cipta, 2001),39.

${ }^{14}$ Sugiyono, Metode Penelitian Pendidikan Pendekatan Kuantitatif, Kualitatif, Dan $R$ \& D (Bandung: Alfabeta, 2009), 336.

${ }^{15}$ Matthew B. Miles dan A. Michael Huberman, Analisis Data Kualitatif. Terj. Tjetep Rohendi Rohidi (Jakarta: UI Press, 2009), 150.
} 
Fatmawati, Penyebab Perceraian ... | 156

eksploratif, dan menggunakan metode induktif-kualitatif, yakni diawali dengan mengungkapkan kenyataan-kenyataan yang bersifat khusus berdasarkan pendapat dan tindakan subyek penelitian.

\section{HASIL DAN PEMBAHASAN}

Pernikahan adalah suatu proses sahnya atau halalnya suatu hubungan badan sesuai dengan akad agama Islam, yang harus dilakukan manusia yang menurut adat, tetapi tidak putus menurut hukum agama, beradab, dan beragama. Hal itu sejalan dengan pandangan yang beranggapan bahwa seseorang dapat dikatakan utuh jika telah melangsungkan pernikahan. Dengan demikian, menjodohkan anak dengan sendirinya berarti menghubungkan atau mempersatukan dua keluarga menjadi satu. ${ }^{16}$ Pernikahan mempunyai hubungan yang erat sekali dengan masalah agama sehingga pernikahan bukan saja bertalian dengan unsur lahiriah atau jasmani, tetapi juga unsur bathiniah yang mempunyai peranan penting dalam kehidupan manusia dan masyarakat. Pernikahan merupakan salah satu cara melanjutkan keturunan dengan berdasarkan cinta kasih yang sah dan dapat mempererat hubungan antarkeluarga, antarsuku, dan bahkan antarbangsa. Hubungan pernikahan merupakan jalinan pertalian yang kuat dalam hidup dan kehidupan manusia. ${ }^{17}$

Namun demikian, hubungan yang disatukan dengan penikahan seringkali mengalami banyak persoalan. Persoalan-persoalan inilah yang kemudian membuat hubungan dalam pernikahan retak, dan jika tidak bisa diselamatkan akan berakibat pada perceraian. Di Kota Palu merupakan kota yang banyak terjadi kasus-kasus perceraian antara suami dan istri dalam keluarga. Perceraian ini terjadi karena persoalan-persoalan antara suami dengan istri dalam keluarga tidak bisa diselesaikan. Di sini ada enam keluarga sebagai sampel penelitian yang mengalami perceraian. Keenam keluarga tersebut disajikan dalam tebel berikut ini.

\footnotetext{
${ }^{16}$ Susan Bolyard Millar, Bugis Wedding; Ritual of Social Location in Modern Indonesia (Makassar: Inmnawa, 2009), 121-22.

${ }^{17}$ Amsari Alip, 'Problematika Perceraian Akibat Selingkuh Dalam Perspektif Hukum Islam. Studi Kasus Tahun 2004-2008 Di Pengadilan Agama Gorontalo’ (UIN Makassar, 2009).
} 
Tabel 1

Identitas Informan Penelitian

\begin{tabular}{|c|l|c|c|c|c|l|}
\hline No. & $\begin{array}{c}\text { Nama } \\
\text { Informan }\end{array}$ & Usia & $\begin{array}{c}\text { Jumlah } \\
\text { Anak }\end{array}$ & Pendidikan & $\begin{array}{c}\text { Penghasilan/ } \\
\text { Bulan }\end{array}$ & $\begin{array}{c}\text { Tingkat Kelas } \\
\text { Ekonomi }\end{array}$ \\
\hline 1 & AW & 56 & 4 & S2 & Rp. 7.000 .000 & Tinggi \\
\hline 2 & IR & 40 & 2 & S2 & Rp. 3.500.000 & Tinggi \\
\hline 3 & BL & 51 & 4 & STM & Rp. 4.500.000 & Tinggi \\
\hline 4 & UP & 38 & 1 & S1 & Rp. 3.000.000 & Menengah \\
\hline 5 & AL & 42 & 2 & SMA & Rp. 2.000.000 & Menengah \\
\hline 6 & SW & 40 & 1 & SMA & Rp. 1.000.000 & Rendah \\
\hline
\end{tabular}

Sumber : Olahan Data Primer Informan Penelitian, Tahun 2021

Dari keenam keluarga tersebut, maka dapat diidentifikasi bahawa fenomena terjadinya perceraian di Kota Palu salah satu sebabnya adalah lebih didominasinya kenyataan hubungan suami dengan istri yang kurang pengertian dan paham pada tugas dan fungsi sebagai suami istri. Fenomena tersebut tidak hanya terjadi pada Kota Palu, tetapi gejala seperti di atas sudah mentradisi dalam kehidupan rumah tangga secara totalitas. Dalam kaitan ini, maka untuk menjaga hubungan keluarga agar jangan terlalu rusak dan berpecah belah maka Islam membolehkan perceraian sebagai jalan keluar bagi suami istri yang telah gagal mendayung bahtera keluarganya. Dengan demikian hubungan antara suami dengan istri dan anak-anaknya berjalan tidak baik. $^{18}$

Persoalan-persoalan itulah yang kemudian memboilehkan adanya perceraian. Dengan adanya perceraian itu bukanlah berarti bahwa agama Islam menyukai atau sekurang-kurangnya bersifat pasif terhadap kemungkinan-kemungkinan terjadinya perceraian dari suatu pernikahan. Atau, boleh dilakukan setiap saat yang dikehendaki, akan tetapi agama Islam tetap memandangnya sebagai suatu yang bertentangan dengan azas dari suatu peraturan perundang-undangan yang berlaku sekarang ini mengisyaratkan bahwa perceraian itu pada hakekatnya dibenci tetapi kalau upaya perdamaian tidak berhasil maka barulah perceraian itu diperbolehkan. Jadi, perceraian itu dibolehkan bukanlah sebagaimana yang dipahami oleh beberapa

${ }^{18}$ Arifin, Dinamika Dan Persoalan Dalam Pendidikan (Jakarta: Media Grafika, 2011), 45. 
kalangan bahwa begitu terjadi perselisihan paham antara suami istri dapat dilakukan perceraian apalagi kalau yang menghendaki perceraian itu datangnya dari suami karena talak berada di tangan suami, melainkan dibolehkan sebagai obat dan sebagai jalan keluar bagi suatu kesulitan yang tidak dapat dipecahkan lagi atau sebagai obat suatu penyakit parah yang tidak ada obatnya lagi selain perceraian.

Jelaslah bahwa perceraian menurut pandangan agama Islam dan peraturan perundang-undangan yang berlaku dalam hal ini pelaksanaannya dilakukan oleh Pengadilan Agama bagi yang beragama Islam merupakan jalan terakhir untuk mengatasi permasalahan rumah tangga atau suami istri yang telah ditimpa perselisihan setelah segala upaya perdamaian tidak berhasil. Oleh karena itu meskipun perceraian dibolehkan dan diatur oleh peraturan perundang-undangan yang berlaku namun tetap dipandang sebagai sesuatu yang bertentangan dengan azas dan tujuan pernikahan, jadi dibolehkan dalam keadaan terpaksa bilamana dipandang hanya itu satu-satunya jalan untuk mengatasi permasalahan rumah tangga yang bersangkutan.

Fenomena ril pada Pengadilan Agama Kota Palu Sulawesi Tengah setelah memperhatikan perkara perceraian, terutama pada tahun 2017-2021 yang paling banyak adalah perkara cerai, baik yang diajukan oleh suami maupun yang diajukan oleh istri. Kalau diperhatikan kebanyakan faktor penyebabnya adalah berasal dari suami istri itu sendiri atau faktor intern. Dalam hal ini, berdasarkan hasil observasi penulis di Kantor Pengadilan Agama Palu dan hasil cara penulis dengan beberapa informan, ditemukan faktor penyebab perceraian bersifat intern sebagai berikut.

\section{Salah Satu Pihak Meninggalkan Kewajiban}

Dengan terjadinya pernikahan antara seorang pria dengan seorang wanita, maka timbul pula hak dan kewajiban antara keduanya. Jadi pria mempunyai kewajiban sebagai suami dan perempuan punya kewajiban sebagai istri. Namun, suami atau istri sering tidak melaksanakan kewajibannya disebabkan beberapa hal seperti kawin paksa, suami tidak mempunyai pekerjaan tetap, suami merantau dan sebagainya. Seperti apa yang dialami oleh ibu AL (janda dua anak) yang tinggal di Kelurahan Donggala Kodi, perceraian yang dialami pada lima tahun lalu, terjadi karena bapak 
atau suaminya betul-betul tidak punya pekerjaan yang menetap. Bahkan, untuk menghidupi kedua anaknya hanya bersumber dari penghasilan istri, yakni ibu AL. Demikian pula dengan kawin paksa, di Pengadilan Agama Palu menurut Drs. Khalis, MA ada dua bentuk, yaitu pernikahan yang dilaksanakan atas kemauan orang tua suami atau istri, dengan tidak meminta persetujuan yang bersangkutan.

Kenyataan ini banyak terjadi di kalangan pernikahan keluarga, maksudnya antara suami istri masih ada hubungan keluarga sehingga sesudah terjadi pernikahan salah seorang atau keduanya tidak melaksanakan kewajibannnya sebagai suami atau istri sehingga terjadi perceraian. Pernikahan paksa dalam bentuk seperti tersebut banyak didapati di kalangan suku Bugis dan Kaili, yaitu suku yang paling banyak berdomisili dalam wilayah hukum Pengadilan Agama Palu, yang beranggapan bahwa kawin keluarga itu baik untuk mendekatkan kembali hubungan keluarga yang sudah mulai jauh seperti anggapan mereka kalau sepupu dua kali dikawinkan, maka hubungan keluarga kembali dekat. Namun kalau di antaranya terjadi perselisihan, maka yang terjadi bukan semakin dekat, tetapi semakin jauh. Hubungan keluarga menjadi retak. Kebiasaan pelaksanaan pernikahan seperti itu pada hakikatnya bertentangan azas yang dianut oleh Hukum Islam dan Peraturan Perundang-undangan yang berlaku yaitu azas sukarela.

Pernikahan paksa dalam bentuk kedua yang banyak pula didapati pada Pengadilan Agama Palu, yaitu akibat pergaulan bebas yang tidak mengenal batas, dimana suami istri sebelum pelaksanaan pernikahan telah melaksanakan hubungan seksual yang kadang-kadang mengakibatkan kehamilan, maka terpaksa harus dilaksanakan pernikahan karena hal seperti itu bila tidak dilaksanakan kemungkinan dapat mengakibatkan pertumpahan darah antara keluarga karena merasa dipermalukan. Pernikahan paksa dalam bentuk seperti itu banyak pula berakibat cerai karena setelah terjadi pernikahan biasanya pria atau suami tidak mau melaksanakan kewajibannya sebagai suami karena suami merasa hanya kawin dipaksa dalam hal ini sering terjadi setelah akad nikah suami langsung meninggalkan istri dikenal dengan kawin turun atau kawin untuk menutupi malu.

Meninggalkan kewajiban biasa pula terjadi karena faktor ekonomi, seperti karena suami tidak mempunyai penghasilan tetap sehingga kewajiban untuk memberi 
nafkah kepada istri tidak dapat terpenuhi, ini biasanya terjadi karena kesiapan untuk melakukan pernikahan belum ada termasuk kemampuan memberi nafkah sehingga menimbulkan penderitaan bagi istri dan anak-anaknya karena kebutuhan hidupnya yang semestinya ditanggung oleh suami menjadi tanggungan orang lain atau terpaksa istri harus mencari nafkah sendiri. Perceraian seperti itu biasanya dimohonkan oleh istri karena ketidakmampuannya menanggung penderitaan yang berkepanjangan.

Salah seorang dan suami atau istri tidak melaksanakan kewajibannya sering pula terjadi karena selalu berpisah tempat tinggal. Salah seorang di antaranya sering bepergian apakah itu disebabkan karena pekerjaannya yang harus menghendaki demikian atau karena salah seorang diantaranya yang tidak tahan di daerah tempat tinggalnya sehingga lebih senang tinggal di kampung halaman sehingga pemberian nafkah baik lahir maupun bathin sulit dapat terlaksana, dan bilamana hal itu sudah dianggap satu penderitaan oleh salah seorang diantara suami atau istri maka tidak jarang pula dapat berakhir dengan perceraian yang disebabkan oleh faktor sebagaimana yang telah diuraikan, yakni karena meninggalkan kewajiban paling banyak didapati pada peristiwa perceraian yang terjadi di Pengadilan Agama Palu dengan jumlah keseluruhan perceraian yang terjadi mencapai $45,38 \%$ disebabkan karena faktor intern, yakni keretakan dalam lingkungan rumah tangga disebabkan pihak suami meninggalkan kewajiban untuk menafkahi istri dan anak-anak mereka. Data seperti ini penulis juga menemukannya dari hasil observasi dan berdasarkan wawancara dan beberapa informan di Kota Palu.

\section{Krisis Akhlak}

Dalam membentuk rumah tangga bahagia dan kekal seperti yang diidam-idamkan oleh pasangan suami istri memang banyak tergantung dari akhlak suami istri karena kerusakan akhlak dapat membawa kehancuran, bukan saja terhadap suami istri tetapi juga terhadap masyarakat. Oleh karena itu, krisis akhlak sering pula mengarah kepada perceraian seperti suami atau istri bermain judi, mabuk-mabukan, pencuri dan atau salah satu diantaranya berbuat serong dengan laki-laki atau perempuan lain. Kalau salah seorang suami atau istri yang sering melakukan hal-hal tersebut, maka dapat dipastikan bahwa antara suami istri itu selalu terjadi perselisihan dan pertengkaran 
karena kurangnya perhatian terhadap keperluan rumah tangga di mana orang yang gemar bermain judi bila telah asyik tidak merasa waktu berlalu, apalagi kalau sudah mabuk-mabukan mengakibatkan orang hilang keseimbangan dan di saat itu kemungkinan untuk melakukan kejahatan sangat besar seperti melakukan penganiayaan terhadap pihak lain bahkan sampai kepada perbuatan zina dan dari sekian banyak perceraian yang disebabkan karena krisis akhlak tersebut di Pengadilan Agama Palu sekitar 6,62\% dan karena penyebab-penyebab tersebut perceraian kebanyakan dimohonkan oleh pihak istri atau cerai atas gugatan istri.

\section{Cemburu}

Sebenarnya cemburu itu merupakan bukti cinta dengan kata lain kalau suami atau istri masih cemburu berarti suami atau istri masih suka atau cinta namun cemburu yang keterlaluan dapat pula mengakibatkan percekcokan bahkan sampai kepada keretakan rumah tangga dan tidak jarang mengarah pada perceraian apalagi kecurigaan suami atau istri tidak benar, atau suami atau istri melakukan tindakan yang dapat menyinggung perasaan salah satu pihak. Perselisihan suami istri bermula dari rasa cemburu ini yang berakhir dengan perceraian didapati di PengadiJan Agama Palu berkisar 3,01\% dari seluruh perceraian yang terjadi. Dari sini dipahami bahwa faktor cemburu menjadi penyebab terjadinya perceraian di Kota Palu.

\section{Penganiayaaan}

Kalau dilihat perkara perceraian pada Pengadilan Agama Palu yang disebabkan karena alasan penganiayaan, yaitu salah satu pihak menganiaya pihak lain, maka yang paling banyak adalah penganiayaan yang dilakukan oleh pihak suami yang sebenarnya berasal dari pertengkara dengan berbagai sebab, ada penganiayaan yang dilakukan karena cemburu ada hubungan dengan laki-laki lain, adakalanya bersumber dari permasalahan anak, atau pengaturan belanja atau masalah kecil yang bermula dari pertengkaran mulut kemudian emosi yang tidak dapat dikendalikan, maka terjadilah penganiayaan yang dalam hal ini banyak dilakukan oleh suami terhadap istri daripada dengan penganiayaan yang dilakukan oleh istri terhadap suami hal ini berkisar 2,40\% dari keseluruhan perceraian yang terjadi di Pengadilan Agama Palu, 
Fatmawati, Penyebab Perceraian ... | 162

sehingga dipahami bahwa penganiayaan dalam bentuk kekerasan dalam rumah tangga (KDRT) merupakan penyebab terjadinya perceraian di Kota Palu.

\section{Penyakit Impotensi}

Penyakit yang merupakan cacat biologis yang biasa dijadikan alasan perceraian seperti impoten, yaitu ketidakmampuan suami memberi nafkah batin kepada istrinya atau tidak dapat memberi kepuasan bathiniah kepada istri baik yang disebabkan karena faktor umum atau penyakit bawaan sejak kelahiran dan penyakit-penyakit lain di mana hal itu menimbulkan penderitaan bagi istri. Kemudian bagi perempuan atau istri biasa pula dijadikan alasan suami untuk cerai karena tidak dapat melahirkan keturunan (mandul) demikian pula penyakit-penyakit lainnya yang membahayakan pihak lain seperti penyakit kusta, gila dan lain-lain. Perceraian semacam ini berkisar 3,01\% dari jumlab peristiwa perceraian di Pengadilan Agama Palu, sehingga dipahami bahwa adanya cacat biologis masuk penyebab perceraian di Kota Palu.

\section{Perselisihan Terus Menerus}

Perselisihan terus menerus dalam rumah tangga biasanya terjadi karena kurangnya saling pengertian antara suami istri seperti salah seorang selalu memaksakan kehendaknya kepada pihak lain. ${ }^{19}$ Salah satunya yang emosional, saling mempertahankan pendirian, tidak mau diajak kompromi yang kesemuanya mengakibatkan tidak adanya ketenangan maka biasanya suami atau istri tidak senang berada dalam rumah tangga yang pada gilirannya membawa perceraian. Perceraian semacam ini banyak pula didapati pada Pengadilan Agama Palu baik yang diajukan oleh suami maupun yang diajukan oleh istri berkisar $29,51 \%$ dari perceraian yang terjadi, sehingga dipahami bahwa karena perselisihan dalam rumah tangga menjadi penyebab terjadinya perceraian di Kota Palu.

\section{Poligami Tidak Sehat}

Perceraian yang disebabkan karena suami kawin lebih dan satu orang biasanya terjadi karena salah seorang istri yang menganggap dirinya tidak diperlakukan sama dengan yang lain baik dalam pemberian nafkah maupun dalam pemberian fasilitas lainnya

\footnotetext{
${ }^{19}$ Abdul Djamil, Aneka Perceraian Di Indonesia (Jakarta: Ghalia Indonesia, 2000), 78.
} 
serta perhatian dari suami atau salah seorang diantara istri yang menginginkan mendapat perhatian yang lebih besar mengakibatkan terjadinya perselisihan dan bilamana tidak dapat diatasi akan berakhir dengan perceraian. Perceraian semacam ini berkisar $1,80 \%$, sehingga dipahami bahwa dengan alasan poligami yang tidak sehat merupakan penyebab terjadinya perceraian di Kota Palu.

\section{Faktor Eksternal}

Selanjutnya penyebab lain perceraian di Kota Palu yang tergolong sebagai faktor eksternal yang penulis temukan berdasarkan hasil observasi, adalah pereraian yang terjadi karena adanya pihak ketiga, bukan bersumber dari suami istri seperti:

a. Pihak orang tua yang terlalu banyak ikut campur dalam urusan rumah tangga anaknya atau keluarganya misalnya orang tua tidak menginginkan anaknya berpisah dengan dia atau selalu ingin berkumpul dengan anaknya sedang pihak suami atau istri tidak menginginkan. Adapula orang tua yang masih ingin mengatur penghasilan anaknya sehingga istri merasa kurang diperhatikan oleh suaminya atau orang tua yang selalu mencari-cari kesalahan menantunya lalu dilaporkannya kepada anaknya. Pihak suami atau istri yang menganggap dirinya kurang mendapat perhatian itulah yang sering meminta cerai dari suami atau istrinya.

b. Pihak lain yang sengaja mengganggu rumah tangga seseorang dengan jalan mengadu domba suami istri dengan berbagai cara bahkan dengan fitnah karena tidak senang melihat rumah tangga seseorang itu baik. Perceraian dengan sebab seperti tersebut terdapat pada Pengadilan Agama Palu sekitar 2,40\% pada perceraian yang terjadi tahun 2021. Dari faktor-faktor penyebab perceraian pada Pengadilan Agama Kota Palu sebagaimana telah diuraikan di atas, dapat diklasifikasi menjadi dua, yakni pada persoalan moral dan perselisihan yang secara terinci sebagaimana tabel berikut : 
Fatmawati, Penyebab Perceraian ... | 164

Tabel 2

Klasifikasi Faktor Penyebab Perceraian di Kota Palu

\begin{tabular}{|c|c|l|c|}
\hline No. & $\begin{array}{c}\text { Penyebab } \\
\text { Utama }\end{array}$ & \multicolumn{1}{|c|}{ Klasifikasi Penyebab } & $\begin{array}{c}\text { Jumlah } \\
\text { kasus }\end{array}$ \\
\hline 1 & Moral & $\begin{array}{l}\text { - Meninggalkan kewajiban } \\
- \text { Krisis akhlak } \\
- \text { Cemburu } \\
- \text { Penganiayaan (kekejaman jasmani, kekejaman } \\
\text { mental, dan dihukum) }\end{array}$ & 122 kasus \\
\hline 2 & Perselisihan & $\begin{array}{l}\text { - Poligami tidak sehat } \\
- \text { Kawin paksa } \\
- \text { Kawin di bawah umur } \\
- \text { Cacat bilogis dan Impotensi } \\
- \text { Pengaruh politis } \\
- \text { Gangguan pihak ketiga }\end{array}$ & 290 kasus \\
\hline
\end{tabular}

Sumber Data: Kantor Pengadilan Agama Kota Palu, tahun 2021

Pernikahan merupakan pintu gerbang yang sah untuk membangun rumah tangga sakinah. Dari lembaga penting ini dibangun suatu tatanan kehidupan keluarga dan masyarakat. Berumah tangga berarti memasuki sebuah hubungan asmara yang diridhai Allah swt. bagaimana membina pernikahan yang bahagia, sakinah dan harmonis. Menurut Khalis, MA, keharmonisan rumah tangga tidak hanya ditentukan oleh melimpahnya harta dan menggebunya rasa cinta, karena kedua hal ini kadang bersifat temporer. Adakalanya harta itu habis atau pailit adakalanya cinta itu melemah. Di awal pernikahan mungkin cinta itu menggebu-gebu tapi setelah sekian lama bisa saja ia luntur. Untuk itu, dalam upaya membina keharmonisan rumah tangga perlu diperhatikan berbagai aspek secara menyeluruh, di antaranya peranan masing-masing istri dan suami, baik yang individual maupun yang dimiliki bersama.

Selain itu, harus dibulatkan niat (tekad), sekali menikah adalah untuk selamanya dan jangan sampai sedikitpun terbetik di dalam pikiran bahwa pernikahan akan berakhir dengan perceraian, karena sesungguhnya Allah Swt., sangat membenci 
perceraian itu. Seorang istri sebagai ibu dari anak-anaknya berkewajiban memenuhi tugas hidupnya untuk membimbing, mengasuh dan mendidik anak-anaknya, mengurusi rumah tangga dengan tertib, sehingga seluruh anggota keluarga menikmati ketenangan dan ketentraman di dalam mengarungi naik turunnya gelombang kehidupan, dalam keadaan suka dan duka. Perlu dipahami bahwa nikah itu melahirkan sejumlah kebebasan, akan tapi di dalam waktu yang sama nikah juga melahirkan keterbatasan dan keterikatan. ${ }^{20}$ Setelah menikah kebebasan pribadi mulai terikat kepada kepentingan bersama dan keluarga. Karena itu, saling pengertian merupakan bagian terpenting untuk mewujudkan kehidupan rumah tangga yang harmonis, rukun dan bahagia. Tak ada gading yang tak retak, tak ada manusia yang sempurna. Itulah pepatah pang patut dicamkan dalam hati.

Kehidupan rumah tangga penuh dengan suka dan duka, penuh liku-liku yang baik dan buruk, suami istri terkadang menjauh setelah sebelumnya bersatu padu, terkadang bertengkar setelah tadinya bercinta kasih, dan berpisah setelah sebelumnya berkasih sayang. ${ }^{21}$ Karena itulah ketenangan keluarga berbalik kepada cuaca yang panas dan buruk. Pertengkaran dimulai dengan sebab-sebab yang sepele dan apinya membesar dari keburukan yang kecil. Atau dalam jiwa suami bergejolak faktor-faktor psikologis atau pemicu dari luar yang membuatnya beranggapan bahwa pernikahan itu merupakan api neraka. Namun, terkadang kebengkokan itu datang dari pihak istri kalau ia berlebihan dalam tuntutannya menutup mata dan selainnya serta berpurapura tidak melihat kepada orang lain yang lebih tinggi, baik kedudukan maupun harta maka ia meratapi nasibnya menjauhi kecocokan dengan suaminya serta kehidupan penuh dengan gelombang kemarahan dan kebencian. Mengenai perkara yang diselesaikan di Pengadilan Agama Kota Palu, tergolong variatif dan terjadi pasang surut dipandang daRI sudut kuantitas, dan hal ini dapat dilihat sejak empat tahun terakhir ini, sebagaimana dalam tabel berikut:

\footnotetext{
${ }^{20}$ Dagun, Psikologi Keluarga (Jakarta: Rineka Cipta, 2004), 64.

${ }^{21}$ Jane Brooks, The Process of Parenting (Yogyakarta: Pustaka Pelajar, 2011), 76.
} 
Fatmawati, Penyebab Perceraian ... | 166

Tabel 3

Perkara Cerai Talak yang Diselesaikan di Pangadilan Agama Kota Palu

\begin{tabular}{|c|c|c|c|c|c|}
\hline \multirow{2}{*}{ Tahun } & \multirow{2}{*}{\begin{tabular}{c} 
Jumlah \\
\multirow{2}{*}{ Perkara }
\end{tabular}} & \multicolumn{4}{|c|}{ Hasil Putusan } \\
\cline { 3 - 6 } & & Frekuensi & Persentase & Frekuensi & Persentase \\
\cline { 3 - 6 } & 41 & 34 & 82,93 & 7 & 17,07 \\
\hline 2018 & 54 & 50 & 92,59 & 4 & 07,41 \\
\hline 2019 & 45 & 42 & 93,34 & 3 & 06,66 \\
\hline 2020 & 37 & 35 & 94,59 & 2 & 05,41 \\
\hline 2021 & 177 & 161 & 90,96 & 16 & 09,04 \\
\hline Jumlah & & &
\end{tabular}

Sumber data: Kantor Pengadilan Agama Kota Palu, tahun 2021

Data tersebut di atas, menunjukkan bahwa selama 4 tahun, Pengadilan Agama Kota Palu telah menyelesaikan perkara cerai talak atau suami menjatuhkan talak kepada istrinya sebanyak 177 dan hasil putusannya sebanyak 161 perkara atau 90,96 persen dikabulkan. Sedangkan 16 perkara atau 09,04 persen tidak dikabulkan artinya ditolak, tidak diterima, dicabut atau digugurkan karena tidak mempunyai alasanalasan yang kuat yang diajukan di Pengadilan Agama Kota Palu. Selanjutnya perkara cerai gugat yang diselesaikan di Pangadilan Agama Kota Palu dalam tahun yang sama, 2010 sampai 2021 menunjukkan bahwa selama empat tahun, Pengadilan Agama Kota Palu menyelesaikan perkara cerai gugat atau istri menjatuhkan talaknya kepada suami sebanyak 466 dan hasil putusan sebanyak 459 perkara atau 98,50 persen dikabulkan, sedangkan 7 perkara atau 1,50 persen tidak dikabulkan atau ditolak, tidak diterima, dicabut atau digugurkan karena tidak mempunyai alasanalasan yang kuat yang diajukan di Pengadilan Agama Kota Palu. Hal ini berdasarkan data dalam dalam tabel berikut: 
Tabel 4

Perkara Cerai Gugat yang Diselesaikan di Pengadilan Agama Kota Palu

\begin{tabular}{|c|c|c|c|c|c|}
\hline \multirow{2}{*}{ Tahun } & \multirow{2}{*}{$\begin{array}{c}\text { Jumlah } \\
\text { Perkara }\end{array}$} & \multicolumn{4}{|c|}{ Hasil Putusan } \\
\cline { 3 - 6 } & & Frekuensi & Persentase & Frekuensi & Persentase \\
\cline { 3 - 6 } & 113 & 111 & 98,23 & 2 & 01,77 \\
\hline 2018 & 131 & 129 & 98,47 & 2 & 01,53 \\
\hline 2019 & 112 & 110 & 98,21 & 2 & 01,79 \\
\hline 2020 & 110 & 109 & 99,10 & 1 & 00,90 \\
\hline 2021 & 466 & 459 & 98,50 & 7 & 01,50 \\
\hline Jumlah & & &
\end{tabular}

Sumber data: Kantor Pengadilan Agama Kota Palu, tahun 2021

Tabel tersebut di atas menujukkan tingginya persentase cerai gugat di Kota Palu disebabkan karena tingginya kekerasan yang dilakukan oleh suami kepada istrinya, seperti menganiaya atau memukul tanpa alasan yang jelas kepada istrinya atau kesalahan lain yang dibuat oleh pihak suami sehingga istrinya menderita. Kemudian sebagian lain lagi, ditemukan banyak kasus perselingkuhan yang dilakukan oleh pihak suami, dan bahkan ada yang melakukan perkawinan secara diam-diam tanpa seizin istrinya.

Dengan adanya perkara cerai talak dan cerai gugat yang terjadi di Pengadilan Agama Kota Palu, yang jumlahnya cukup signifikan sebagaimana tabel yang telah disebutkan maka dapat diakumulasi terjadinya perceraian karena adanya fenomena yang didahului perselisihan terus menerus keadaan rumah tangga yang kurang harmonis. Selanjutnya penyebab terjadinya perceraian di Kota Palu dominan karena alasan salah satu pihak meninggalkan kewajiban, krisis akhlak, cemburu, penganiayaan, cacat biologis/penyakit, poligami yang tidak sehat, campur tangan orang tua/mertua dan pihak lain. Persoalan yang sering terjadi dalam kasus perceraian di dalam rumah tangga di Kota Palu dan yang melatarbelakangi, adalah timbulnya persoalan-persoalan yang disebabkan permasalahan dalam keluarga, terlalu terikatnya suami atau istri kepada ibu bapaknya. Setiap ada persoalan dalam keluarga ia segera lari mengadukan pertanda ketidakmatangan emosional, atau dapat pula dikatakan bahwa suami atau istri tersebut mempunyai sikap kekanak-kanakan atau manja yang 
tidak pada tempatnya, sehingga tidak sedikit keluarga yang menjadi retak, bahkan membawa kepada perceraian. Hal ini disebabkan karena suami atau istri berlaku patuh kepada orang tuanya, di mana kehidupan keluarga selalu diatur dan dicampuri oleh orang tua. Kalau persoalan-persoalan seperti ini tidak diatasi antara suami istri sampai berlarut-larut maka yang mengakibatkan rumah tangga akan berantakan disebabkan tidak sanggup lagi mengatasi emosinya yang melahirkan ketegangan, dan sudah tentu membawa kepada perceraian.

\section{KESIMPULAN}

Kota Palu yang memiliki jumlah penduduk 313.179 jiwa, dalam (tiga) tahun terakhir, kasus cerai yang diproses di Pengadialn Agama Palu terus meningkat pada tahun 2018, 2019 dan 2020. Salah satu kota yang banyak terjadi kasus perceraiannya adalah Kota Palu. Berdasarkan data dari Kantor Pengadilan Agama Palu tersebut, menunjukkan bahwa tiga tahun terakhir ini, 80\% kasus perceraian yang pengasuhan anak jatuh pada ibu. Fenomena penyebab perceraian di Kota Palu ditinjau dari segi internal dalam lingkungan rumah tangga terjadi karena salah satu pihak meninggalkan kewajiban untuk mencari nafkah demi kelangsungan hidup keluarga dengan persentase $45,38 \%$, terjadinya krisis akhlak seperti gemar bermain judi, mabuk-mabukan dengan persentase $6,62 \%$, adanya sikap cemburu yang berlebihan yang menyebabkan sakit hati dengan persentase 3,01\%, perselisihan yang terjadi terus menerus dengan persentase $29,51 \%$, poligami tidak sehat $1,80 \%$. Selanjutnya penyebab lain perceraian di Kota Palu ditinjau dari segi faktor eksternal, adalah karena pihak orang tua yang terlalu banyak ikut campur dalam urusan rumah tangga dengan persentase $8,20 \%$, pihak lain sebagai pihak ketiga dengan cara menyebarkan fitnah yang persentasenya mencapai $2,40 \%$. 
169 | MUSA WA, Vol. 13 No.2 Desember 2021 : 150-169

\section{DAFTAR PUSTAKA}

Adrianto, Psikolog Sosial, Jakarta: Erlangga, 2002.

Al-Hamdani, Said Thalib, Rishalatun Nikah, Jakarta: Pustaka Amani, 2000.

Ali, A. Mukti, Beberapa Persoalan Agama Dewasa Ini, Jakarta: Rajawali Press, 2007.

Alip, Amsari, 'Problematika Perceraian Akibat Selingkuh Dalam Perspektif Hukum Islam. Studi Kasus Tahun 2004-2008 Di Pengadilan Agama Gorontalo, UIN Makassar, 2009.

Amato, P.R., Children's Adjustment to Divorce; Theories, Hypotheses and Empirical Soport, New Yor: Jurnal Mariage and Family, 1993.

Arifin, Dinamika Dan Persoalan Dalam Pendidikan, Jakarta: Media Grafika, 2011.

Arikunto, Suharsimi, Manajemen Penelitian, Jakarta: Rineka Cipta, 2013.

Brooks, Jane, The Process of Parenting, Yogyakarta: Pustaka Pelajar, 2011.

Dagun, Psikologi Keluarga, Jakarta: Rineka Cipta, 2004.

Djamil, Abdul, Aneka Perceraian Di Indonesia, Jakarta: Ghalia Indonesia, 2000.

Hadi, Sutrisno, Metode Research, 1st edn, Yogyakarta: Universitas Gajah Mada, 1986.

Huberman, Matthew B. Miles dan A. Michael, Analisis Data Kualitatif. Terj. Tjetep Rohendi Rohidi, Jakarta: UI Press, 2009.

Marpaung, Happy, Masalah Perceraian; Alasan Dan Akibatnya, Bandung: Tons, 2003.

Mattulada, Sejarah Kebudayaan To Kaili Palu, Palu: Lembaga Penerbit Universitas Tadulako, 2010.

Millar, Susan Bolyard, Bugis Wedding; Ritual of Social Location in Modern Indonesia, Makassar: Inmnawa, 2009.

Shihab, M. Quraish, Tafsir Al-Misbah, Jakarta: Lentera Hati, 2006.

Soe'oed, Bunga Rampai Sosiologi Keluarga, Jakarta: Yayasan Obor Indonesia, 2009.

Subagio, Joko, Metode Penelitian Dalam Teori Dan Praktek, Jakarta: Rineka Cipta, 2001.

Sugiyono, Metode Penelitian, Yogyakarta: Rosdakarya, 2010.

- Metode Penelitian Pendidikan Pendekatan Kuantitatif, Kualitatif, Dan R \& $D$, Bandung: Alfabeta, 2009. 